значительной степени - cp. We are in the business cycle with a slightly optimistic outlook/ Bыступая на пресс-конференциии с четверг, Барак Обама выглядел слегка растерянным.

\title{
Лumepamypa:
}

1. Кузнецов, С.А. Большой толковый словарь русского языка / С.А. Кузнецов. - М.: Норинт, 2013. $-242 \mathrm{c}$.

2. Ожегов, С. И. Толковый словарь русского языка / С.И. Ожегов. - М.: Мир и Образование, 2015. $-759 \mathrm{c}$.

3. Сулейманова, О.А., Фомина, М.А. Верификационный потенциал семантического эксперимента // Научный вестник Воронежского государственного архитектурно- строительного университета. Сер. Современные лингвистические и методико-дидактические исследования. 2017ю №2 (34). С. 15-28.

4. Сулейманова, О.А., Фомина, М.А.Триангуляционный подход в экспериментальной лингвистике // Русистика и компаративистика. Научные труды по филологии. 2018. Вып. 12. С. $220-235$

5. Ушаков, Д.Н. Толковый словарь современного русского языка / Д.Н. Ушаков. - М.: Альтапринт, 2008. $-793 \mathrm{c}$.

6. Cambridge dictionary [Электронный pecypc] URL https://dictionary.cambridge.org/ru/ (дата обращения 23.09.2020).

7. Oxford dictionary [Электронный pecypc]URL https://www.oxfordlearnersdictionaries.com (дата обращения 23.09.2020).

DOI 10.33065/978-5-907216-49-5-2021-11-16

И.А. Горшков, сержант, Ярославское высшее военное училище противовоздушной обороны, г. Ярославль, Российская Федерация, Р.О. Коровченко, серэсант, Ярославское высшее военное училище противовоздушной обороны, г. Ярославль, Российская Федерация, Ю.M. Орехова, стариий преподаватель кафедры английского языка Ярославское высшее военное училище противовоздушной обороны, г. Ярославль, Российская Федерация АББРЕВИАЦИЯ В ВОЕННОЙ ЛЕКСИКЕ
СОВРЕМЕННОГО АНГЛИЙСКОГО ЯЗЫКА

Аннотация. Данная статья рассматривает основные вопросы, связанные с процессом аббревиации военной лексике современного английского языка. Проанализирован термин «аббревиация» $u$ определены причины появлений 
сокращений в языке. Дана краткая классификащия лексических сокращений и рассмотрены основные способы образования сокращений на материале военного дискурса современного английского языка.

Ключевые слова: аббревиация, виды сокращений, военная терминология, английский язык.

Ilya A.Gorshkov, Sergeant, Yaroslavl Higher Military Institute of the Air Defense, Yaroslavl, Russian Federation, Rodion O. Korovchenko, Sergeant, Yaroslavl Higher Military Institute of the Air Defense, Yaroslavl, Russian Federation, Yuliya M. Orekhova, Senior Lecturer of Foreign Languages Department, Yaroslavl Higher Military Institute of the Air Defense, Yaroslavl, Russian Federation

\section{ABBREVIATIONS OF ENGLISH MILITARY VOCABULARY}

Abstract. The paper deals with the phenomenon of abbreviation of in the modern English vocabulary for the military. The term "abbreviation» is analyzed and causes of the appearance of abbreviations in the language are identified. A brief classification of lexical abbreviations is given and the main ways of their forming, based on the material of the military discourse of the modern English, are also considered.

Key words: abbreviation; classification of abbreviations, military terminology, English.

Введение. Аббревиация стала одним из самых продуктивных способов пополнения словарного состава терминологии многих языков, в том числе и английского языка. Использование различных видов сокращений является, своего рода, ответной реакцией на появление многокомпонентных терминологических сочетаний в различных профессиональных сферах деятельности человека.

По этой причине проблема использования в устной и письменной речи разнообразных сокращений становится предметом пристального исследования лингвистов. Так, в отечественном языкознании аббревиация стала предметом 
исследования в работах следующих лингвистов: Д.И. Алексеевой [1], И.В. Арнольд [2], В.В. Борисова [3] и многих других отечественных лингвистов.

Основная часть. Несмотря на большое количество работ по исследуемой проблеме, сокращенные лексические единицы продолжают вызывать у лингвистов многочисленные споры. Это также обусловлено и тем, что применительно к сокращениям приходится рассматривать такие проблемы языкознания, как структура слова и его семантика и произношение, производной и производящей единицы. Также «проблемность» рассматриваемого вопроса обусловлена разными мнениями относительно классификации и типологии сокращений в военном дискурсе [5, с.118].

Актуальность исследования обусловлена тем, что военный дискурс изобилует сокращениями, которые зачастую встречаются в анализируемых на учебных занятиях текстах и вызывают у курсантов трудности понятийного характера при их переводе, при построении устного или письменного высказывания и выполнении заданий на двусторонний перевод.

Целью настоящей статьи является выявление особенностей сокращений в военной лексике современного английского языка, что предполагает решение следующих задач:

- анализ понятия «аббревиация»;

- выявление причин появления сокращений в языке;

- представление классификации сокращений;

- описание основных способов образования сокращений в языке.

Источниками языкового материала для исследования послужил «Англорусский словарь сокращений по авиационной и ракетно-космической технике» [6] и учебно-методические пособия, используемые на практических занятиях по английскому языку в ЯВВУ ПВО (г. Ярославль).

Итак, современное состояние английского языка характеризуется процессами глобализации, которые привели к появлению особого рода 
наименований объектов, предметов и понятий, в результате чего возник огромный пласт сокращенной лексики [4, с. 10].

Курсанты военного вуза постоянно сталкиваются с явлением аббревиации в учебной деятельности и повседневной жизни. Появление сокращений в военной лексике современного английского языка обусловлено тем, что, во-первых, в военном терминологическом аппарате преобладают длинные словосочетания и труднопроизносимые термины, а, во-вторых, в современной армии постоянно появляется множество новых понятий, что влечет за собой образование новых терминов.

Смысл сокращения лексических единиц заключается в обеспечении передачи смыслового содержания при минимальном использовании звуковой оболочки и графической формы слова, что приводит к повышению эффективности коммуникативной функции языка. То есть, понятие «аббревиация» может быть рассмотрено как экономии языковых средств: из отдельных частей реально существующих слов и словосочетаний образуются новые, ранее не существовавшие единицы - аббревиатуры» [7, с. 17].

Вслед за исследователем В. В. Борисовым мы будем определять термин «сокращение» (аббревиация) как единицу устной и письменной речи, созданную из отдельных элементов звуковой или графической оболочки слова или словосочетания, с которой данная единица находится в определенной лексикосемантической связи [3, с. 100].

Анализ научных работ исследователей (Д.И. Алексеева [1], И. В. Арнольд [2], В.В. Борисов [3], Е.Г. Пыриков [7] и др.) позволил нам выявить следующие основные причины возникновения сокращений в военной лексике современного английского языка:

- научно-технический прогресс;

- «гонка вооружения»; 
• военные конфликты, революции и прочие социальные сдвиги;

- необходимость в экономии речевых средств при построении высказывания;

- ассимиляция заимствованных из других языков слов;

- потребность в новых словах, образующихся в соответствии с присущими аббревиации закономерностями;

• тенденция языка к моносиллаболизму.

Классификация сокращений в самом общем виде может быть представлена следующим образом (см. Схема 1).

\section{Схема 1. Классификация сокращений в современном английском языке}

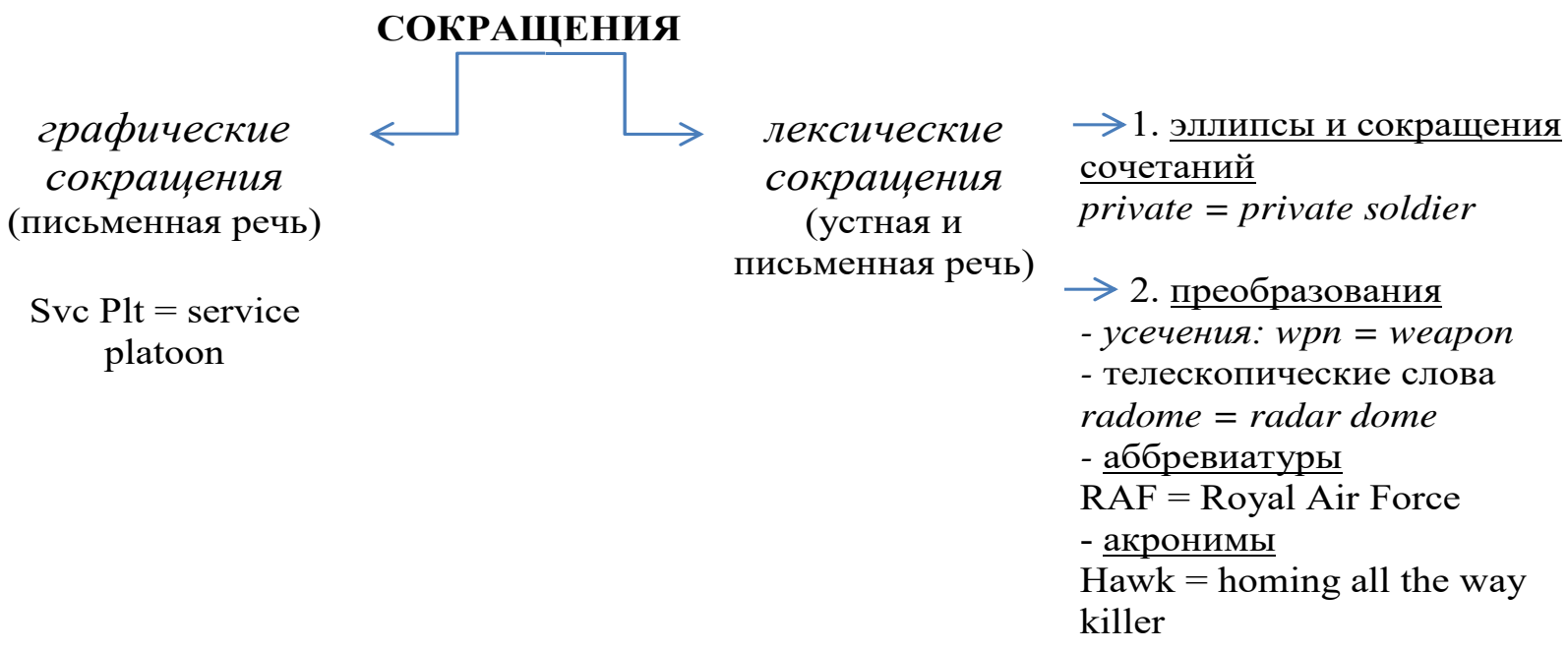

Рассмотрим основные способы образования сокращений на материале военного дискурса современного английского языка.

В большинстве случаев аббревиатура состоит из начальных и конечных букв слова, а из букв, находящихся между нами, выбираются важные буквы, слов или сочетание звуков:

a) начальные буквы однословного термина: P-pilot, F-fighter, R-radius.

б) начальные буквы элементов термина, состоящего из нескольких слов: N.F.-night fighter, JF - jet fighter, MAM - medium altitude missile. 
в) начальные буквы элементов термина, являющегося сложным словом: ls loudspeaker, yb - yardbird.

г) первая часть термина: Mech - mechanized.

д) первые части элементов термина, состоящего из нескольких слов: raddef radiological defense.

е) опущение большинства гласных и некоторых согласных: inf - infantry, wpn weapon, armd - armoured.

ж) использование буквы вместо обычного префикса или первой части слова: $\mathrm{xtr}-$ transmitterю

3) начальная и конечная часть термина: avn-aviation.

Заключение. Таким образом, аббревиация широко распространена в военном терминологическом аппарате современного английского языка. Мы выяснили, что причины, влияющие на появление сокращений, во многом связаны со всемирными глобальными процессами и технологизацией общества. Очевидно, что сокращения являются неотъемлемой составной частью военной лексики и важным источником ее пополнения.

\section{Лumepamypa:}

1. Алексеев, Д. И. Аббревиация в условиях научно-технической революции // Научнотехническая революция и функционирование языков мира. - М. : Наука, 1977. - С. 31-217.

2. Арнольд, И. В. Лексикология современного английского языка. - М., 1959. - 176 с.

3. Борисов, В. В. Аббревиация и акронимия / // Военные и научно-технические сокращения в иностранных языках. - М. : Воениздат, 1972. - 319 с.

4. Воробьева И.А. Аббревиация как способ словообразования современного английского языка // Казанский вестник молодых ученых. - №4 (7). - 2018. - С. 10-13.

5. Кубышко, И. Н. Аббревиация - закономерное явление в английском языке // Омский научный вестник. - № 6 (102). - 2011. - С. 118-121.

6. Мурашкевич А. М., Владимиров О. Н. Англо-русский словарь сокращений по авиационной и ракетно-космической технике: около 30000 сокращений. М.: Воениздат, 1981. - 621 с.

7. Пыриков, Е. Г. Сокращаемые слова в языках с иероглифической и алфавитной системами письма : дис. ... канд. филол. наук. - М.: Военный институт, 1984. - 182.

8. 